\title{
REVIEW ON THE INVESTMENT EVALUATION OF DEPARTMENT OF MARITIME AFFAIRS AND FISHERIES ASSET (COLD STORAGE) AT PARIGI MOUTONG REGENCY, CENTRAL SULAWESI, INDONESIA
}

\author{
Mardjudo Ahsan*, Alatas Umar, Yahya Fachrudin A. \\ Study Program of Fisheries Agribusiness, Faculty of Fisheries, University of Alkhairaat, \\ Palu, Indonesia \\ *E-mail: ahsan.mardjudo@gmail.com
}

\begin{abstract}
In general, this research aims to examine and analyze the investment evaluation on the development of cold storage as the local government asset. This research also aims to give suggestion to the Government of Parigi Moutong Regency in policy making that supports the asset utilization process in the economic development in Parigi Moutong Regency region, Central Sulawesi Province, Indonesia. Data collection in this study is done by conducting the direct survey in the location of cold storage development in Bolano Tengah Village regarding its existence and capacity and also by interviewing the related local government regarding capitalization and operational cost, as well as the impact of cold storage development in that region. The data is processed using financial and socio-economic analysis. The research results show that the value of NPV amounted to Rp20,601,212,191., Internal Rate of return (IRR) amounted to 47\%., Net B/C Ratio 2.11., and a Payback period of 8.2 years. Hence, the development of cold storage is feasible and prospective to be carried out economically and financially. Socio-economically, the existence of the facility like cold storage in an area will affect the level of the community's income because it will encourage the economic activities. One of the real things is that the infrastructure development project in that region will attract the community to do economic activities such as selling crops or other food ingredients. These kinds of activities will add the value as well as increasing the community's income in that area. It will also open employment for the community around the area.
\end{abstract}

\section{KEY WORDS}

Investment evaluation, cold storage, community, development.

Cold storage is a room exclusively for storing goods that require cold temperature. The existence of cold storage is an inseparable part of a series of fishery activities in a primary sub-system, secondary sub-system, and tertiary sub-system. The tertiary sub-system is a fishery system that carries out handling, storage, transportation, and selling activities. This sub-system does not make any change to the fishery products but only held the products until there is the consumer who wants to buy it. Cold Storage for fishery has the functions as follows: a) Center for collecting fishery that will be marketed, b) Processing and/or preservation place of frozen fishery products that will increase the economic added value for business actors, c) Stabilizer for the price of fishery commodity in their region, d) The existence of Cold Storage create employment such as seller, labor, and staff, e) Means of training, internship, and development for students or community, f) Improve the regional economy through centrifugal effect that triggers the productivity of other sectors. Hence, it creates an income multiplier effect for Gross Regional Domestic Product/GRDP.

The Government of Parigi Moutong Regency, Central Sulawesi Province, Indonesia, through Department of Maritime Affairs and Fisheries has implemented several strategic steps through the program to improve the competitiveness of marine and fishery products. One of the strategies for the government to encourage the economic growth of the coastal community is by establishing infrastructures close to each other to be used to maintain the quality of the catch. The solution is cold storage. The development of cold storage program is a form of or part of the government investment that expect economic growth in the form of the increase of coastal community's income and the establishment of employment for the 
community. The development of cold storage is expected to influence the economic changes for the coastal community (fisherman and cultivator in the sea).

The development of this facility is to provide fish storage needs for the fisherman and seller before it is marketed. The purpose of this storage is to keep the quality of catch as well as to guarantee their goods during the handling and marketing processes. In general, the establishment of fish cold storage factory is expected to increase the sales value of fisherman's catch and the seller. This will automatically improve the welfare value and standard of living of coastal community where most of its people work as a fisherman. The effort to develop fishery business through the improvement of marketed product quality in the regional level up to international requires the support of the existence of various fishery facilities (infrastructure) such as cold storage facility.

Establishment and development of fishery infrastructure in every region are expected to be the center of the economic center in order to improve production, processing, and marketing in local, national, and international scales. Furthermore, Lubis (2002) explained that the development of the fishery economy should be supported by the fishery industry both in the upstream and downstream. In addition, there should be the development of human resources, especially the coastal community.

The realization of cold storage that is capable to play its role maximally is not a burden of one party. In this case, the local government is the sole party. More likely it is a synergistic effort from various parties such as Government (center, province, and regency/city) as the administrator and/or donor. Private party as the donor and stakeholder on this fishery facility, the community as its economic units and University as the contributor for opinion/analysis on the step/strategy to be taken to achieve optimum cold storage function. Related to the effort in realizing the cold storage facility in Parigi Moutong Regency, the study on "the Investment Evaluation of Department of Maritime Affairs And Fisheries Asset (Cold Storage) In Parigi Moutong Regency Sulawesi Tengah" is important to do because the review on the level of operationalization feasibility of cold storage currently and in the future include various main aspects such as environment, social, and economy (financial) technical. The purpose of investment evaluation on the development of cold storage as the local government asset is to give input to the Government of Parigi Moutong Regency in the decision making that supports the utilization process of the asset in the economic development in Parigi Moutong Regency area.

\section{METHODS OF RESEARCH}

Theoretical Framework. Based on Law No, 31 of 2004 which is amended in Law No $45 / 2009$ Fishery is all activities related to the management and utilization of fish resources and their environment ranging from preproduction, production, processing to marketing carried out in a fishery business system. Meanwhile, the fish resources are the potential of all types of fish. Fish itself is all types of organisms that where its life cycle is in the aquatic environment is wholly or partly (cited from Primyastanto, 2011).

One of the absolute needs required to encourage fishery industry activity and realize the program of improving the welfare of the coastal community is by providing adequate facility and infrastructure. The facility and infrastructure here are fishery ports equipped with other supporting facilities as the basis of activities to procure fisheries production on the coast and become the center of communication between activities in the sea and land area (Murdiyanto, 2002).

The establishment of the fish port or fish catch landing dock (PPI) in an area is expected to anticipate the development of existing fisheries activities in an effort to improve the economy of the fisheries sector (Directorate General of Fisheries, 1981). According to Rukhimat (1992), fish catch landing dock (PPI) is a place for fishermen to collect their catch or as the fish port in a smaller scale.

According to Bagakali (2000), the building facility for fish auction plays an important role because it can increase the economic value of fishery production landed in the port. The auction building is a core part of all facilities in the fishing port and supporting facilities and 
infrastructure. The success of fisheries activities, especially fishery catch, cannot be separated by the availability of adequate supporting facilities and infrastructure. Some of the facilities that are closely related to the development of special fisheries for marine fisheries are Fisheries Port (PP) and Fish Catch Landing Dock (PPI).

According to Sunariyah (2003), investment is capital investment in one or more owned assets. It usually has a long-term period in the hope of gaining profits in the future." Today, many countries carry out policies to increase both domestic and foreign investment. This is done by the government because investment activity will encourage the economic activities, employment, improvement in the generated output, exchange saving or exchange improvement of the country.

According to Husnan (1996), the investment project is a plan to invest resources both in large and small projects to obtain benefits in the future. In general, these benefits are in the form of the value of money. Meanwhile, capital can be in the form other than money such as land, machinery, building, and others. However, both the investment expenditure side and the obtained benefits must be converted into the value of money. An investment plan should be analyzed thoroughly. The analysis of the investment plan is basically research concerning whether a project (either large or small) can be implemented successfully or not. It can also be stated as an exploratory method of a business idea about the possibility of whether the business idea is feasible or not.

An investment project generally requires large fund and it will affect the company in the long term. Therefore, careful investment planning is required to avoid investing in an adverse project.

According to (www.sinarharapan.co.id/ekonomi/eureka/2003/021/eur1.html), some of the reasons to invest are (a) Productivity of a person that keeps declining (b) the uncertainty of the economic environment that allows the possibility where income is much smaller than expenditure (c) Basic needs that tend to increase.

Investment for business will face two alternatives namely profitable investment and adverse investment. Therefore, a feasibility study must be done before making the decision to invest in a certain amount of funds. The purpose of this feasibility study is to find out whether the business carried out is feasible or not. Investment assessment functions as a planner as well as an evaluation of a project or work carried out in accordance with the planning (Riyanto, 2002). Furthermore, investment is the entire planning and decisionmaking process regarding the expenditure of funds where the period of return of the funds exceeds a year.

According to Fattah (2002), investment or capital budgeting put by someone or company is the policy taken to issue a number of funds both for business development and to get certain benefits. And good planning process should be carried out to ensure that the fund will quickly return to the case within a certain period of time. A certain level of profit from the results of the business can be used as working capital.

The existing investment in the company should be utilized at best. The reason is that the wrong use of investment can be detrimental to a business that will be carried out. This means that investment is always oriented to the profits derived from a business or company. Hence, the issued investment not only can be returned on time but can also provide certain benefits for the company.

In the calculation of national income and statistics, investment covers a wider range. In the calculation of national income, investments cover: "The whole purchasing value of entrepreneur on capital goods and spending to establish industry, public expenditure to build houses and residences, increase in the value of the stock of goods in the form of raw materials, unprocessed goods, and finished goods. (Sukirno, 1994)

In the Keynesian model, it is assumed that all income must be spent for consumption or must be saved, and the amount of economy can be divided into two which are between expenditure on consumer goods and capital goods, and the position of balance in the economy is determined when the amount of revenue equals the amount of expenditure. Hence, investment is equal to saving. 
In relation to the company where it makes an investment to get the maximum profit, where one of the investment funds comes from public funds that are deposited in financial institutions, it can be stated that: Investment is the overall expenditure of the company which includes expenditures to buy raw materials, machinery and factory's equipment and all other capital needed in the production process. The expenditures are for office building utilities, factory where employees live and other construction buildings. The changes in stock value or reserve goods are the results from the changes of amount and price". (Deliarnov, 1995)

In carrying out company activities, investment is one of the things that have a very important role. The reason is that investment is related to how a group of people or organization will make a business or company. Hence, it requires the fund to support its business operations. In this case, the fund is a very important part to finance the operational activity of the company.

To analyze the purpose of this research, several approaches or methods are carried out in the investment evaluation. Application of investment evaluation method as an analytical tool is to determine the level of business feasibility in investing. The purpose of this assessment is to avoid wasting the budget and it can also assist in the use of fixed capital and current capital to avoid payment for substantial capital interest expenses. The feasibility of an investment can be assessed by equipment or profitability method, revenue cost ratio (RC ratio) and Break Event Point (BEP) analysis for a short-term period. Long-term analyses are Payback Period (PP), Net Present Value (NPV), Internal Rate of Return (IRR) and Profitability index (PI) or Benefit Cost Ratio (BCR).

Research Site. Review on the Investment Evaluation of the Department of Maritime Affairs and Fisheries Asset (Cold Storage) In Parigi Moutong Regency, Central Sulawesi Province, Indonesia. The research site was in Bolano Tengah Village at Parigi Moutong Regency.

Data Collection Method:

Literature study is conducted by a team to get a theory that can help in analyzing the investment feasibility and the renting fee of cold storage asset of the Department of Maritime Affairs and Fisheries Parigi Moutong Regency.

Conducting a direct survey in the cold storage development location in Bolano Tengah Village concerning its existence and capacity it has

Conducting interviews with the government regarding business processes related to capital and operating costs needed, interview with the fishermen to find out the revenue and income from the fishing business they carry out an interview with the community related to the impact of the construction of existing cold storage.

Taking pictures at the study location used camera equipment. The images include: cold storage infrastructure, the condition and activities of the fishing community, the condition of fisheries and marine resources and others.

Data Analysis. Data to be analyzed come from the secondary and primary data that were collected during the field survey. Data analysis was carried out qualitatively for socioeconomic and cultural aspects of data. Meanwhile, data on economic/financial aspects will be analyzed quantitatively with economic tools. They are income analysis, Payback Period (PP), Net Present Value (NPV), Internal Rate of Return (IRR) and Benefit Cost Ratio (BCR), as well as socio-economic impact analysis towards the coastal community.

\section{RESULTS AND DISCUSSION}

Analysis on the Potential of Fishery Resources and Marketing Pattern of the Catch. The potential of fishery resources in Parigi Moutong Regency is quite big both for catch fishery or the cultivation. According to the Agency for Marine and Fisheries Research (2004), Parigi Moutong Regency has a coastline of 472 kilometers and a catch area of $\pm 28,208 \mathrm{~km}^{2}$. With such potential, it is estimated that it has a sustainable potential of catch fisheries of 587,250 tons per year, consisting of large pelagic fish of 106,000 tons, small pelagic fishes of 379,440 tons, demersal fish of 83,840 tons and other fish species of 17,970 tons. In term of fishpond products according to the Department of Maritime Affairs and Fisheries of Sulawesi 
Tengah (2006), Parigi Moutong Regency is the milkfish producer area with a harvest area of 3,362 ha and production of $12,335.3$ tons and productivity of 3.6 tons/ha. But over time, the harvest area for fishponds (milkfish and shrimp) spread throughout the sub-district area of $6,875.7$ ha in 2017. Most of the land is productive land to be developed. Hence, people in Parigi Moutong Regency continue to strive to increase the productivity of milkfish pond cultivation.

The fishery resource is one of the national assets that must be managed properly. Improvement in the science and technology fields is expected to be able to support the management of fisheries resources. Hence, it can improve the quality and quantity of fisheries production as a foreign exchange earner. The fishery is an economic activity where humans seek their fishery natural resources sustainably in order to get the maximum benefit for the welfare of mankind. The development of the fisheries sub-sectors aims to improve the welfare of fishermen and fish farmers towards the realization of a fair and prosperous society. According to Law of Republic of Indonesia No. 31 of 2004 jo. Law No. 45 of 2009 concerning Fisheries stating that activities that are included in the fisheries start from preproduction, production, processing to marketing, which are carried out in a fisheries business system.

In order to utilize the existing natural resources potential, especially the one concerning the development of fisheries in a broader meaning, an approach through the product is carried out. That is planning the development of catch fisheries and aquaculture areas. Conception about the development of aquaculture areas in spatial planning is more directed to how to provide spatial management direction for a fishery area, especially the regional fisheries production center area. Planning for development of catch fisheries and aquaculture areas is an effort to utilize the existing land/potential in overcoming the problems faced in the management and arrangement of fisheries in rural areas. Management of catch fisheries and aquaculture space is the direction of policy and strategy for spatial use for fisheries and other fisheries-based businesses on a

An aquaculture area that has been developed should have the following characteristics:

1) Most community activities in a coastal area are dominated by fishing and aquaculture activities in a whole and integrated system starting from:

a. Upstream minabusiness subsystems include: research and development, fishery facilities, capitalization, and others;

b. Catch/aquaculture business subsystem which includes the business of: fish seeding, fish enlargement and provision of aquaculture facilities;

c. Downstream minabusiness which includes: processing industries (freezing, fumigation, scanning) and marketing includes trade for export activities,

d. Subsystem support services (activities that provide services for minabusiness) such as: credit, insurance, transportation, education, counseling, infrastructure, and government policy.

2) There is a connection between urban and rural linkages that are reciprocal in which they need each other, where aquaculture area in the countryside develop cultivation (on farm) and processed products on a household scale (off farm), on the contrary the city provide facilities for the development of cultivation and business activities such as the provision of fisheries facilities such as: capital, technology, information, fishing equipment and so on;

3) The activities of most of the community in that area are dominated by aquaculture activities, including industrial business (processing) of fishery products, trade in fishery products (including trade for export activity), upstream trade minabusiness (fisheries and capital facilities), mina tour and services.

Analysis on the Socio-Economy Condition of the Community. The existence of the facility like cold storage in an area will affect the level of the community's income because it will encourage the economic activities. One of the real things is that the infrastructure development project in that region will attract the community to do economic activities such as selling crops or other food ingredients. These kinds of activities will add the value as well 
as increasing the community's income in that area. Mardjudo A., and Yasin Muhammad (2017) stated that the activities of the coastal community including fishermen who can bring household income are activities in the field of fisheries and non-fisheries. Fishery business includes all of the activities related to the catching fish and processing of catch fish. Whereas non-fisheries are all activities related to the activities of selling agricultural products, becoming construction workers and becoming security in the company in coastal areas which is not engaged in fisheries.

The development of cold storage by the Department of Maritime Affairs and Fisheries as the asset of the local government of Donggala Regency receives a good response by the surrounding community and community in general in that region. The survey results show that the cultivating and fishing communities strongly support the existence of cold storage on the grounds that it makes it easier for them to sell fishpond and catch fish. On the other hand, they revealed that the cold storage factory (local reading) was very good because it was clear about the market and the price at which we brought the existing production.

In this social impact sub-chapter, direct observation in the field shows that the construction of cold storage from environmental aspects will not cause pollution because there is no waste from activities in cold storage that can cause environmental pollution. As a brief description of the activities in the processing process including the stages of measurement of the size, product weighing, entering in ABF until the packing process almost do not create any waste that can pollute the environment.

Analysis of the economic impact on the development of cold storage is expected to give the chance or opportunity to the community in this area such as being the workers. In reality, the workers who are involved in cold storage processing consist of permanent and temporary workers. Permanent workers are recruited from the qualification requirements of having a high school education, Diploma, and Bachelor degree. Meanwhile, non-permanent staff or freelancers are recruited from those who have a junior high school, elementary school, and even elementary school qualifications. In this study, we need to explain briefly that the task of non-permanent staff is a measurement of size (there is already a standard for it), weighing, and laying down and processing the product in maintaining the quality of fish with ice that has not been entered into the ABF.

In the economic aspect of natural resources, the existence of cold storage encourages the community to have production equipment and patterns of use or utilization of fish cultivation land specifically for community fish cultivation business. The ownership pattern of production tools or technology becomes very important in improving the production as well as improving the community's household income. According to Mardjudo A., et.,al (2016), the improvement of coastal community or fishermen household income can be done through the improvement of husband's efforts in the fisheries field. Therefore, the existence of cold storage as the government program has generally encouraged the improvement and welfare of the community.

The purpose of the government in investing or developing the asset in an area is expected to be the center of economic growth. One of the indicators as the center of economic growth is that every infrastructure facility has always been proven by the opening of production roads which can be followed by the desire of the community to build settlement house in the region. By using this, the construction of public facilities such as educational infrastructure and religious service are the priority of the government in that region. The expectation for contribution to the income of local revenue (PAD) will be realized when there are economic activity and growth.

The construction of cold storage in the Parigi Moutong Regency can be realized and it has environmental social economic benefits in a sustainable manner by considering the following matters.

Given the huge amount of costs needed in the construction of cold storage facilities and the operationalization of daily activities, there should be a capital sharing between local government and business actors who have a high interest in investing in fisheries Even if this facility is fully funded and run by the private sector, there must be coordination and monitoring by local government and the community to avoid monopolistic phenomena that 
can have a major impact on community fisheries business (for example, stagnancy in fisheries product distribution and various expensive retribution which ultimately affect the reduction in profit).

At the beginning of the year of the construction of cold storage until the end of the business period ended, it was ensured to be able to overcome unfavorable conditions as presented in the financial sensitivity analysis

Managers and the Department of Maritime Affairs and Fisheries must be able to maintain the continuity of fish raw materials per month. Efforts that can be made are to establish cooperation or partnership with producers of milkfish/shrimp/tuna (farmers, fishermen, and collectors) in and outside Parigi Moutong Regency by paying attention to several things, namely:

- Purchasing of tuna/milkfish/shrimp at prices that are in accordance with local collectors or fisheries agents in the city of Surabaya. Shrimp purchase is made in cash and a delay in payment should not exceed 1 day;

- Providing incentives for each quantity of tuna/milkfish/shrimp sold by producers to managers in the form of money, prices, goods, and others as bonuses;

- Provision of price information on a regular basis which can foster a sense of trust in producers of cold storage managers;

- Providing socialization and information on business development;

- If the cold storage has been able to achieve the desired profit, there should be an effort for lending or capital strengthening credit to producers (fishermen/cultivators), this can provide a social bond between the producers and cold storage managers;

- Stipulated rent cost as an attraction for prospective cold storage users, as well as the benefits they get from the existence of this facility;

- It is necessary to do socialization on the existence of cold storage facilities in Bolano Tengah to sellers in the Parigi region and its surroundings. Thus, they can utilize these facilities to maintain the quality of goods in the form of fish for a certain period of time to be sold the next day. Hence, the level of loss of traders due to unsold goods can be kept to a minimum.

Table 1 - Operational and Maintenance Cost of Cold Storage per Month

\begin{tabular}{|c|c|c|}
\hline No & Component & Total (Rp.) \\
\hline & Capital Modal & \\
\hline A. & Non-Fixed Cost & \\
\hline \multirow[t]{4}{*}{1.} & Milkfish Purchase & \\
\hline & - Size $5-10$ & $143,000,000$ \\
\hline & - Size $11-12$ & $77,000,000$ \\
\hline & - Size U - 12 & $24,000,000$ \\
\hline 2. & Transportation cost (Bolano-Pantoloan) & $5,000,000$ \\
\hline 3. & Freelance worker salary (30 people) & $6,300,000$ \\
\hline 4. & Electricity & $14,000,000$ \\
\hline 5. & Ice & $1,500,000$ \\
\hline 6. & Dos & $1,500,000$ \\
\hline 7. & Raffia Rope & 500,000 \\
\hline \multirow[t]{2}{*}{8.} & Plastic Wrap & 750,000 \\
\hline & Total Cost (A) & $273,550,000$ \\
\hline \multirow[t]{6}{*}{ B. } & Fixed Cost & \\
\hline & - Fuel & $2,000,000$ \\
\hline & - Labor & $11,250,000$ \\
\hline & - Maintenance & $5,000,000$ \\
\hline & - Depreciation & $16,291,238$ \\
\hline & Total Cost (B) & $28,826,238$ \\
\hline C. & Total Cost $(\mathrm{A}+\mathrm{B})$ & $308,091,485$ \\
\hline
\end{tabular}

Source: Primary processed data, 2018.

Economic and Financial Analysis. Input that is distinguished by fixed input and variable input is required to get frozen fish production. Fixed input is input in which its amount does not depend on the amount of output of catch and aquaculture fish commodities. Meanwhile, 
variable input is the input that only depends on the number of entered or supplied fish from producers (fishermen or fish farmers).

Investment Fee. The survey results show that cold storage factory is very suitable to be built in Bolano Tengah Village Parigi Moutong Regency with a land area of 2,500 $\mathrm{m}^{2}$ which is owned by Department of Maritime Affairs and Fisheries of Parigi Moutong Regency. This factory is equipped with facilities and infrastructure and other supporting facilities such as processing rooms, frozen fish storage, sources of clean water, security fences, and electricity using PLN and/or generators. It is estimated that the amount of investment fee required for the construction of Cold Storage Rp. 1,544,550,532 (Bolano Tengah Village).

Operational and Maintenance Cost. The operational activity of cold storage, especially in terms of purchasing fish raw materials, freezing process and selling outside the area requires operational and maintenance costs for the assets owned. The amount of operational and maintenance costs for each month is estimated at Rp.308,091,485. With the highest operational costs absorbed by the procurement (purchase) of fish raw materials at an average price of Rp. 10,500, - per kilogram an average of 30 tons per month amounting to Rp. 244,000,000. Electricity supply is assumed to come from PLN and Generator. The need for operational and maintenance costs is shown in Table 1.

Production and Revenue from Frozen Fish Processing Facilities. Production capacity is carried out by approaching the availability of raw materials, assuming that the establishment of cold storage is intended to absorb the production of milkfish/tuna and shrimp produced by fishermen and cultivators in the Parigi Moutong Regency without ignoring the requirements of the Good Aquaculture Product. Production generated from the Cold Storage (capacity of 30 tons) includes monthly sales of fish for an average of Rp. 432,000,000 with the following assumptions: frozen fish production takes 10-12 hours (ABF process) as much as 1-3 tons. Hence, in a month (30 days) it ranges from 20-30 tons per month for the first year to the third year with estimates of production of both marine and ponds products that are still fluctuating and the assumption of revenue and sales in a year is only 10 months.

Table 2 - Estimated Production and Annual Cold Storage Revenues

\begin{tabular}{|c|c|c|c|c|}
\hline Year & Month & Production $(\mathrm{kg})$ & $\begin{array}{c}\text { Price } \\
\text { average }\end{array}$ & Income \\
\hline 1 & 10 & 210,000 & 13,333 & $2,799,930,000$ \\
\hline 2 & 10 & 240,000 & 13,333 & $3,199,920,000$ \\
\hline 3 & 10 & 300,000 & 13,333 & $3,999,900,000$ \\
\hline 4 & 10 & 400,000 & 13,333 & $5,333,200,000$ \\
\hline 5 & 10 & 600,000 & 13,333 & $7,999,800,000$ \\
\hline 6 & 10 & 700,000 & 13,333 & $9,333,100,000$ \\
\hline 7 & 10 & 800,000 & 13,333 & $10,666,400,000$ \\
\hline 8 & 10 & 900,000 & 13,333 & $11,999,700,000$ \\
\hline 9 & 10 & $1,000,000$ & 13,333 & $13,333,000,000$ \\
\hline 10 & 10 & $1,200,000$ & 13,333 & $15,999,600,000$ \\
\hline
\end{tabular}

Source: Primary Processed Data, 2018.

Table 3 - Net Cash Revenue of Cold Storage Utilization

\begin{tabular}{|c|c|c|c|}
\hline Year & Income & Depreciation & Net Cash (Process) \\
\hline 1 & $19,085,147$ & $162,914,853$ & $182,000,000$ \\
\hline 2 & $99,085,147$ & $162,914,853$ & $262,000,000$ \\
\hline 3 & $284,085,147$ & $162,914,853$ & $747,000,000$ \\
\hline 4 & $559,085,147$ & $162,914,853$ & $3,562,000,000$ \\
\hline 5 & $3,399,085,147$ & $162,914,853$ & $5,222,000,000$ \\
\hline 6 & $5,059,085,147$ & $162,914,853$ & $6,402,000,000$ \\
\hline 7 & $6,239,085,147$ & $162,914,853$ & $7,917,000,000$ \\
\hline 8 & $7,754,085,147$ & $162,914,853$ & $9,502,000,000$ \\
\hline 9 & $9,339,085,147$ & $162,914,853$ & $9,502,000,000$ \\
\hline 10 & $9,339,085,147$ & $162,914,853$ & \\
\hline
\end{tabular}

Source: Primary Processed Data, 2018. 
Projection of Profit and Loss. The projection of profit and loss shows that the first year of this business has obtained Net Cash (Profit) of Rp. 182,000,000. The acquisition of details of operating profit losses from the sale of frozen fish from fish processing can be shown in the following table 3.

Projection of Financial Feasibility. Business cash flow projection of fish freezing for 10 years can be shown in the table. Business feasibility can be analyzed by analyzing return period, Internal Rate of Return, Net Benefit Cost Ratio, and Net Present Value. The results of the analysis using the Excel Finance program is shown in table 4.

Table 4 - Business Feasibility of Cold Storage Utilization

\begin{tabular}{|c|c|c|c|}
\hline No & Feasibility criteria & Value & Description \\
\hline 1 & NPV DF 12\% & $20,601,212,191$ & feasible \\
\hline 2 & IRR $(\%)$ & 47 & Feasible \\
\hline 3 & Net B/C Ratio & 2.11 & Feasible \\
\hline 4 & Payback Period & 8.2 & Feasible \\
\hline
\end{tabular}

Source: Primary Processed Data, 2018.

The existence of cold storage facilities in Parigi Moutong Regency is estimated to be able to produce a total discounted benefit of 10 years for its managers amounted to Rp. $1,450,415,385.20$ with a net value (NPV) of Rp. 20,601,212,191. This provides an interpretation that net profit accumulation will be obtained during the period of the project in the future with the present value at the amount of that NPV. Financially, the development and utilization of cold storage are feasible and prospective to be implemented because the NPV value is above 0 .

Internal Rate of Return (IRR) Based on the internal rate of return, the existence of prospective cold storage is carried out because the investment invested in the initial year is able to provide a profit of $47 \%$ (IRR> OCC $12.00 \%$ ) during the operation (10 years). Owned investment capital will be more effective in generating economic benefits if it is invested in the construction project and utilization of cold storage compared to when the capital must be deposited in commercial banking. While in the implementation of cold storage operational activities, especially in the case of fish freezing, a Net BC value ratio of 2.11 is produced. It means that the generated profit during the cold storage business operational has amounted to 2,11 times of the total investment costs incurred. For the return on investment in operational use of cold storage, it shows that the payback period is 8.2 years. Hence, it is feasible to be implemented before the management period of 10 years. After the Payback period, the fish freezing facility will provide benefits for 1 year 10 months for the manager.

\section{CONCLUSION}

The feasibility and business financial analysis of the cold storage is used to obtain a financial picture of business income and costs, business capacity and feasibility. These calculations require basic calculations based on the results of the survey and observation in the field.

Cold Storage Factory in Bolano Tengah Village Parigi Moutong Regency has a land area of $2,500 \mathrm{~m} 2$. This factory is equipped with facilities and infrastructure and other supporting facilities such as processing rooms, frozen fish storage, sources of clean water, security fences, and electricity using PLN and/or generators. It is estimated that the amount of investment fee required for the construction of Cold Storage Rp. 1,544,550,532.

The operational activity of cold storage requires operational cost and maintenance cost for its assets. The amount of operational and maintenance costs for each month is estimated at Rp. 308,091,485 consisting of fixed cost amounted to Rp. 34,541,485, - and non-fixed cost amounted to Rp. 273,550,000. With the highest operational costs absorbed by the procurement (purchase) of fish raw materials at an average price of Rp. 10,500,- per kilogram. 
Frozen fish production takes 10-12 hours (ABF process) as much as 1-3 tons. Hence, in a month (30 days) it ranges from 20-30 tons per month for the first year to the third year with estimates of production of both marine and ponds products that are still fluctuating and the assumption of revenue and sales in a year is only 10 months Production generated from the Cold Storage (capacity of 30 tons) includes monthly sales of fish for an average of Rp. $432,000,000$. Commodity needs of fish to be frozen depending on the availability of catch production and cultivation from the community, the readiness of the fish freezing factory and the market in receiving the product.

The existence of cold storage facilities in Parigi Moutong Regency is estimated to be able to produce a total discounted benefit of 10 years for its managers amounted to Rp. $1,927,930,343$, - with a net value (NPV) of Rp. 18,708,257,250 ,-. This provides an interpretation that net profit accumulation will be obtained during the period of the project in the future with the present value at the amount of that NPV. Financially, the development and utilization of cold storage are feasible and prospective to be implemented because the NPV value is above 0 .

The investment invested in the initial year was able to provide a profit of $47 \%$ and $38 \%$ (IRR> OCC $12.00 \%$ ) during the operational operation (10 years). The average Net BC ratio is 1.76. It means that the generated profit during the cold storage business operational has amounted to 1,76 times of the total investment costs incurred. For the return on investment in the operation of cold storage utilization, it is illustrated that the average return time for 2 locations for cold storage construction is 7.4 years. Thus, it is feasible to be implemented before the management period of 10 years. After the Payback period, the fish freezing facility will provide an average profit of 2.8 years for its managers.

\section{REFERENCES}

1. Bagakali, 2000. Pedoman Pengoperasian, Pengelolaan and Perawatan Pelabuhan Perikanan. Pusat Kajian Sumberdaya Pesisir and Lautan, IPB Bogor.

2. Dinas Kelautan and Perikanan Sulawesi Tengah, 2006. Annual Report.

3. Ditjen Perikanan, 1981. Standar Rencana Induk and Pokok-pokok Desain Untuk Pelabuhan Perikanan and Pangkalan Pendaratan Ikan. Jakarta: PT. Inconeb.

4. Lubis E, 2002. Pengantar Pelabuhan Perikanan. Teaching Handbook, Mata Kuliah Pelabuhan Perikanan, Fakultas Perikanan and Kelautan IPB.

5. Mardjudo A., Koestiono., Mustadjab, Hanani., 2016. Simulation of Household Economic Policy to Improve Small-Scale Fisherman's Income, Using Rural Rice-Fish Development Program in Donggala, Indonesia. International Jurnal of Management and Admistrative Sciences (IJMAS).

6. Mardjudo A., and Yasin Muhammad., 2017. Household Economic Model to Improve small-scalale Fisherman Income at Rural Minapadi (Rice-Fish System) Development Program In Donggala, Central Sulawesi. Russian Journal of Agricultural and Socioeconomic Sciences. DOI: https://doi.org/10.18551/rjoas.2017-10.35.

7. Murdiyanto, B. 2002. Pelabuhan Perikanan. Bandung: Fakultas Perikanan and Kelautan IPB.

8. Primyastanto, M. 2011. Feasibility Usaha Perikanan sebagai Aplikasi dari Teori Studi Kelayakan Usaha Perikanan. Malang: UB Press.

9. Riyanto B., 2002. Pembelanjaan Perusahaan edisi ke empat. Yogyakarta: Penerbit Yayasan Gadja Mada.

10. Rukhimat E., 1992. Studi Pengembangan Pangkalan Pendaratan Ikan and Kemungkinan Pengembangannya. Bandung: Fakultas Perikanan and Kelautan IPB. 